\title{
ACTIVITY OF THE SCIENTIFIC COMMISSION OF «GROTTA GRANDE DEL VENTO» (Genga, Ancona, Central Italy)
}

\author{
Mario Bertolani* and Arrigo A. Cigna**
}

\begin{abstract}
SUMMARY
The Grotta Grande del Vento (the Great Wind Cave) was discovered in 1971. An administrative body (the "Consorzio Frasassi") under the control of some local authorities took care of its development and the cave was opened to tourists in 1974.

A Scientific Commission formed by some experts (choosen by the Consorzio Frasassi) of different disciplines was established in 1975. During these 15 years the Commission acted as an advisory committee for the Consorzio in order to guarantee the protection of the cave environment.

In particular the Commission set up a monitoring network of the most important environmental parameters (air and water temperature, air currents, relative humidity and $\mathrm{CO}_{2}$ concentration) in some suitable locations and studied the best solutions to avoid algae and other plants proliferation in the vicinity of light sources.

The Commission promoted and directed researches in the karst system under a strict co-operation with the Consorzio Frasassi which funded most of them. Some scientific papers resulted from these researches.
\end{abstract}

\section{RIASSUNTO \\ [L'attivita della Commissione Scientifica della «Grotta Grande del Vento» (Genga, Ancona, Central Italy]}

La Grotta Grande del Vento è stata scoperta nel 1971. Lo sviluppo della grotta venne portato avanti. da un organismo amministrativo (il Consorzio Frasassi) costituito da rappresentanti delle varie alcune autorità locali; la grotta venne così aperta al pubblico .rel 1974.

Nel 1975 venne istituita una Commissione Scientifica costituita da esperti in varie discipline, scelti dal Consorzio. Durante questi 15 anni la Commissione ha funzionato come organo consultivo del Consorzio con lo scopo di garantire la protezione dell'ambiente sotterraneo.

In particolare la Commissione ha dotato la grotta di un sistema di monitoraggio dei parametri ambientali principali (temperatura dell'aria e dell'acqua, correnti d'aria, umidità relativa e concentrazione della $\mathrm{CO}_{2}$ ) in opportuni punti di misura ed ha studiato le migliori soluzioni per evitare la proliferazione di alghe ed altri vegetali in prossimità di sorgenti di luce.

La Commissione ha promosso e diretto studi e ricerche sul sistema carsico in stretta collaborazione con il Consorzio che ha garantito il necessario finanziamento. I risultati di queste ricerche sono stati riportati in alcuni lavori di interesse scientifico.

\section{INTRODUCTION}

The "Grotta Grande del Vento" is one of the most interesting show caves of Europe and belongs to a larger karst system which includes also the near-by «Grotta del Fiume». It is also known under the name of «Grotte di

\footnotetext{
* Ist. Mincralogia, Università, Piazza S. Eufemia 19. I-41100 MODENA (Italy)

** Fraz.. Tuffo, I-14023 COCCONATO (Italy)
} 
Frasassi» but it must be recalled here that in old literature such a name was generically attributed to some minor caves in the same area.

The cave was discovered on 27 September 1971 by some cavers of the Gruppo Speleologico Marchigiano of CAI (Ancona) and the first scientific investigations were carried on by some scientists of the University of Modena in the Spring of the following year (Bertolani et al., 1975; 1976).

During the Summer of 1973 the «Consorzio Frasassi», an organization formed by the Commune of Genga and the Province of Ancona, was founded with the aim of developing and operating a show cave. The inherent works started immediately: an artificial entrance with a tunnel of 223 metres was excavated and on the 1st September 1974 the tourists were admitted to visit the first 850 metres of the cave.

The number of visitors reached a rather high value in a very short time. A comparison of the growth of visitors for the larger show caves in Italy is very interesting. While the growth of the Castellana caves took many years to reach a plateau, the Grotta Grande del Vento reached a steady state in a few months only. The reason of the different behaviour is due both to the location of the caves (quite central for the latter and peripheric for the former cave with respect to the main tourist routes) and to the living habits: in the 70's both private and public transports have much more expanded than in the 50's (Fig. 1).

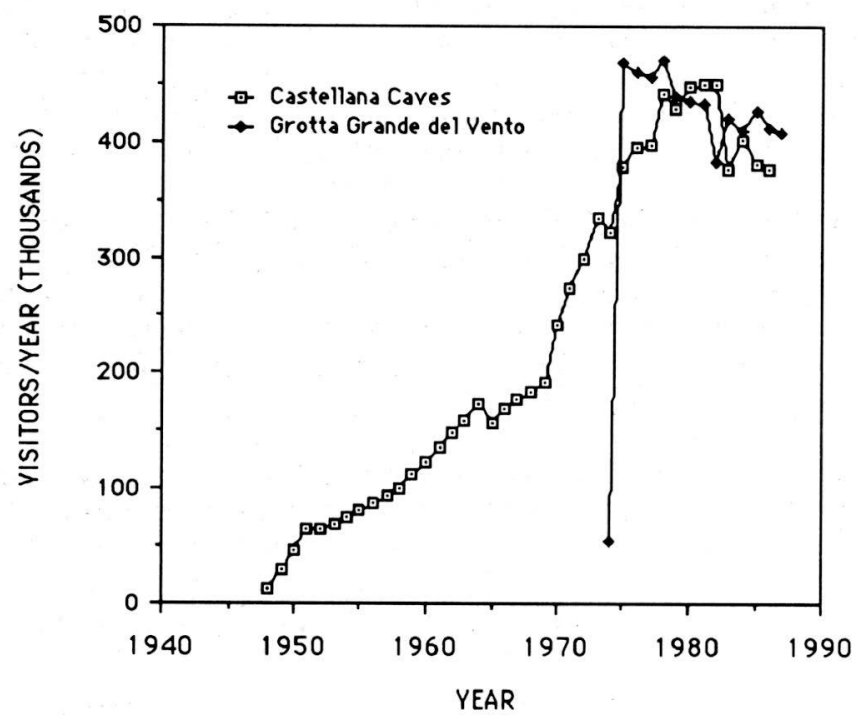

Fig. 1 - The visitors of the Castellana Caves (Bari) and Grotta Grande del Vento (Genga, Ancona) after their development as show caves (Direzione Grotte di Castellana, 1990; Consorzio Frasassi, 1990). 
Because of the great number of visitors the Consorzio Frasassi deemed necessary to start a feasibility study of excavating a new tunnel in order to have a one-way tourist trail with an entrance through the old tunnel and the exit through the new one. To this purpose a Scientific Commission was nominated at the beginning of 1975 with the task of investigating the environmental implicat ions of the new tunnel. In addition the Commission played the role of advising the Consorzio on the scientific researches to be supported and developed in the cave.

The members of the Commission are reported in the following table:

Name

Prof. Franco Anelli

Prof. Mario Bertolani

Prof. Vittorio Castellani

Prof. Arrigo A. Cigna

Prof. Mario Dall'Aglio

Dr. Sergio Macciò

Prof. Lucio Morbidelli

Prof. Gian Paolo Sighinolfi
Field of interest

Speleology, cave management
Applied petrography
Physics
Physics, env. protection
Geochemistry
Speleology
Petrography
Chemistry

Notes

$1975-1977$
Chairman since 1978
since 1979
Chairman $1975 / 1978$
$1976-1979$
Secretary
since 1975
since 1984

In addition some scientific consultants supplied their advices according to the needs of the Commission. During the first years of its activity the Commission was also requested to report on problems of the show cave management, materials to be used in different cave installations and lights. At the same time the Commission had the opportunity to answer questions raised by different local authorities and environmental organizations concerning the works carried on in the cave and their compliance with the protection of the environment.

Another important problem considered at that time was the growth of green plants (especially fungi and algae) in the vicinity of lamps. Such plants develop from spores transported by the visitor's clothes. Some solutions of the problem (disinfection of tourists, inactivation by ultraviolet radiation, inactivation by periods of total darkness) were impossible to apply or scarcely efficient.

Some treatment with chemicals proved to be more convenient. At first an experiment was carried on with "Karmex ${ }^{\mathrm{TM}}$ (Du Pont) according the advice of Prof. V. Caumartin. By taking into account both the chemical toxicity of the products, their aggressiveness on speleothems and the global efficiency, the best results were obtained by spraying an aerosol of an aqueous solution at $50 \%$ of sodium hypocholorite. Some cleverness of the personnel was required in order to reach any point to be treated. 


\section{THE MANUAL MONITORING NETWORK}

The problem of tunnel required many meteorological and climatological data while some measurements only were available on air and water temperature and air humidity obtained during the study carried on in 1972. For this purpose the Commission started a monitoring programme of air temperature and humidity in about 20 stations with measurements to be carried on once a month.

A first set of data enabled the Commission to report a positive answer to the feasibility of a new tunnel with the constraint of air-locks and a severe procedure for their operation in order to exclude any possibility of influencing the equilibrium of the inside atmosphere. For reasons independent from these results such new tunnel was not excavated up to now. The tourist trail was prolonged (up to 1200 metres).

\section{THE FIRST AUTOMATIC MONITORING NETWORK}

In 1982 an automatic network consisting of two stations for the measurement of temperature, humidity and air velocity and a fixed infrared system with 10 sensors for the measurement of carbon dioxide concentration in air (Fig. 2) was set up.

The data obtained by this network emphasized the influence of the flow of tourists on some environmental parameters particularly from July to September when the number of persons is higher than during the rest of the year. In particular in the month of August the air temperature and the concentration of carbon dioxide increased during the day due to the presence of tourists and the night was not long enough to recover the equilibrium values (Fig. 3 and 4).

A failure of the air-lock in the entrance tunnel is rather evident in the bottom curve of Fig. 3 where the diurnal increase of temperature is accompanied by a consistent decrease of humidity. A similar phenomenon is shown by the variation of $\mathrm{CO}_{2}$ concentration reported in Fig. 4: in fact during August 7 and 15 the doors in the entrance tunnel were open all the day long. It should be emphasized the increase of $\mathrm{CO}_{2}$ concentration between these days, which occurs at a rate faster than that observed before August 7, 1989 according to Castellani (1988) this fact could be due not only to the contribution of the visitors but also to the contribution of a natural compartment acting as a reservoir of $\mathrm{CO}_{2}$. On the other hand the peaks due to the visitors at the week-ends are clearly evident during September and October of 1983.

In Fig. 5, the diurnal variation of $\mathrm{CO}_{2}$ concentration are reported for three sampling points during two days; the lowest values and the largest decrease correspond to the point 4 in the map of Fig. 2, which is closer to the entrance 


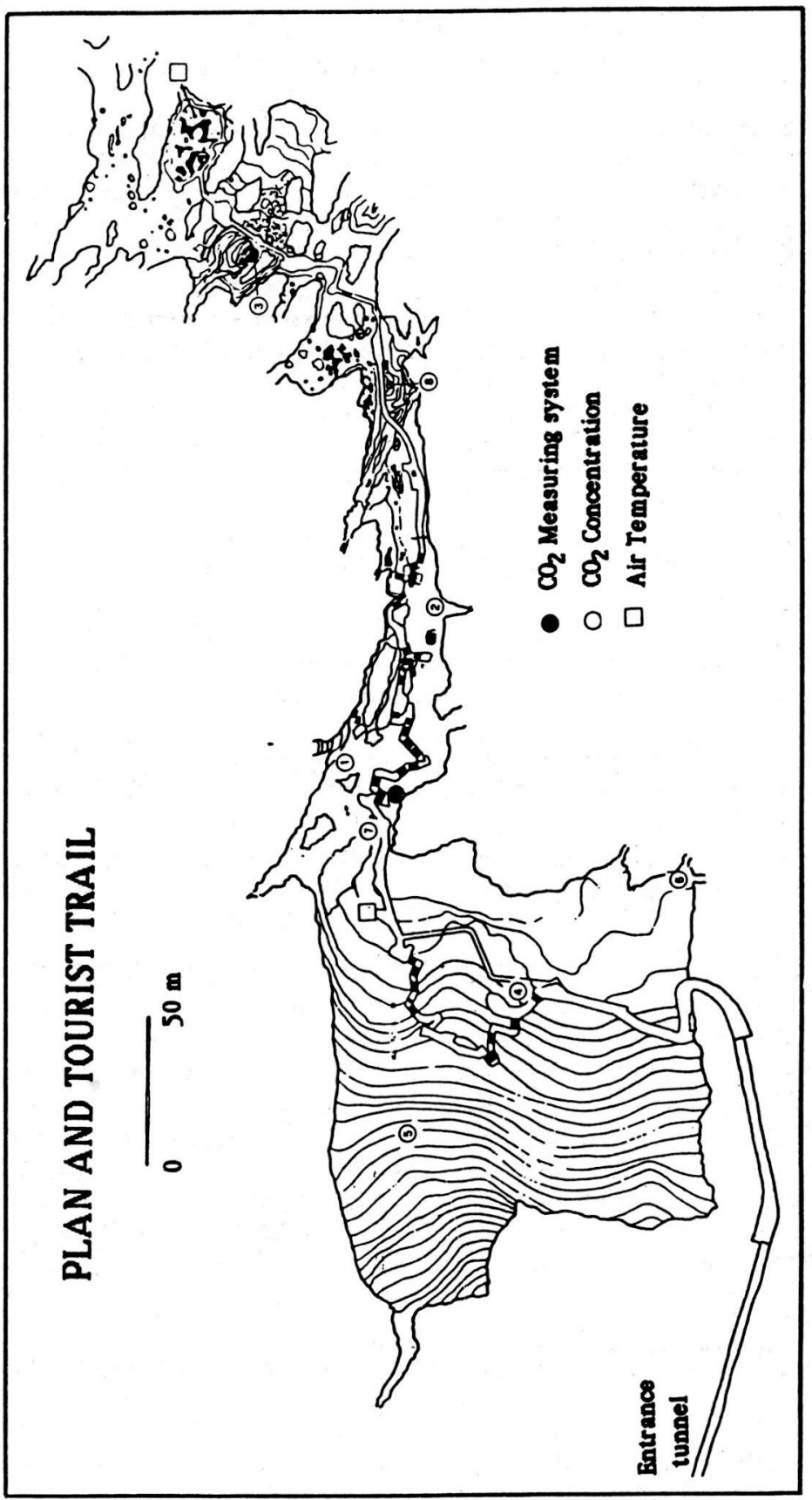

$\infty$
$\infty$
$\infty$

를

롱

氙

5

预

空 


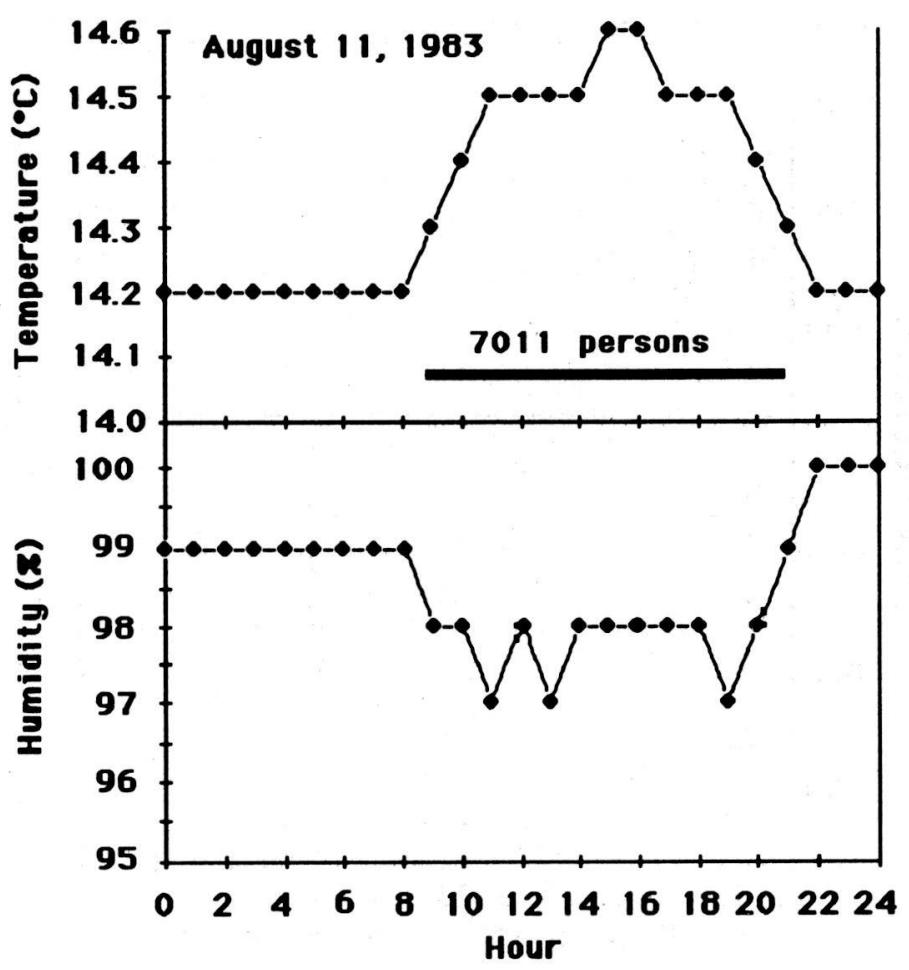

Fig. 3 - Air temperature and relative humidity measured at the bottom of the Ancona Hall (Castellani, 1988).

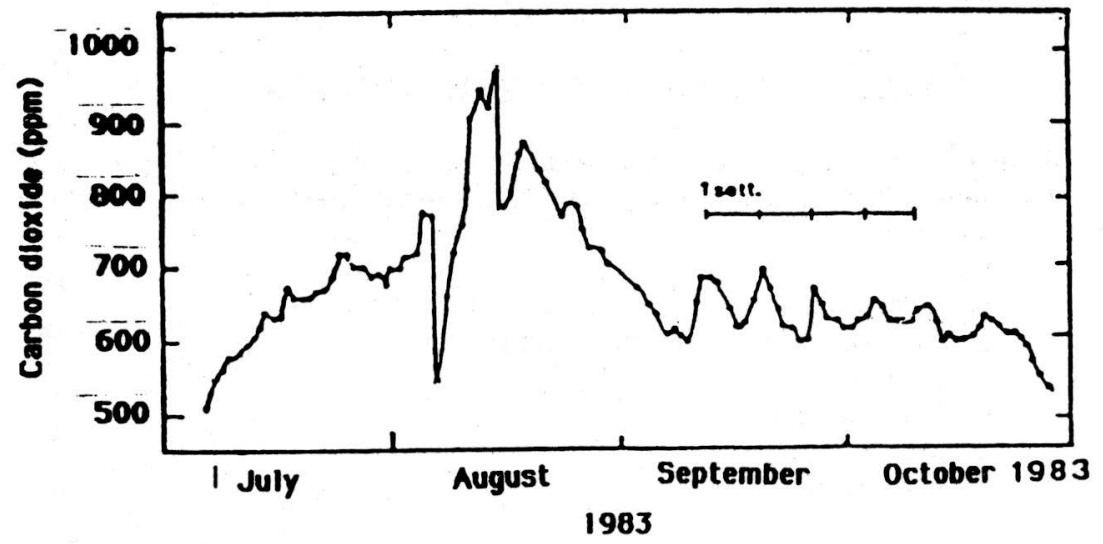

Fig. 4 - Carbon dioxide concentration measured daily at 12 p.m. at the sampling station $\mathrm{N}^{\circ} 8$ in the Ancona Hall (Castellani, 1988) 


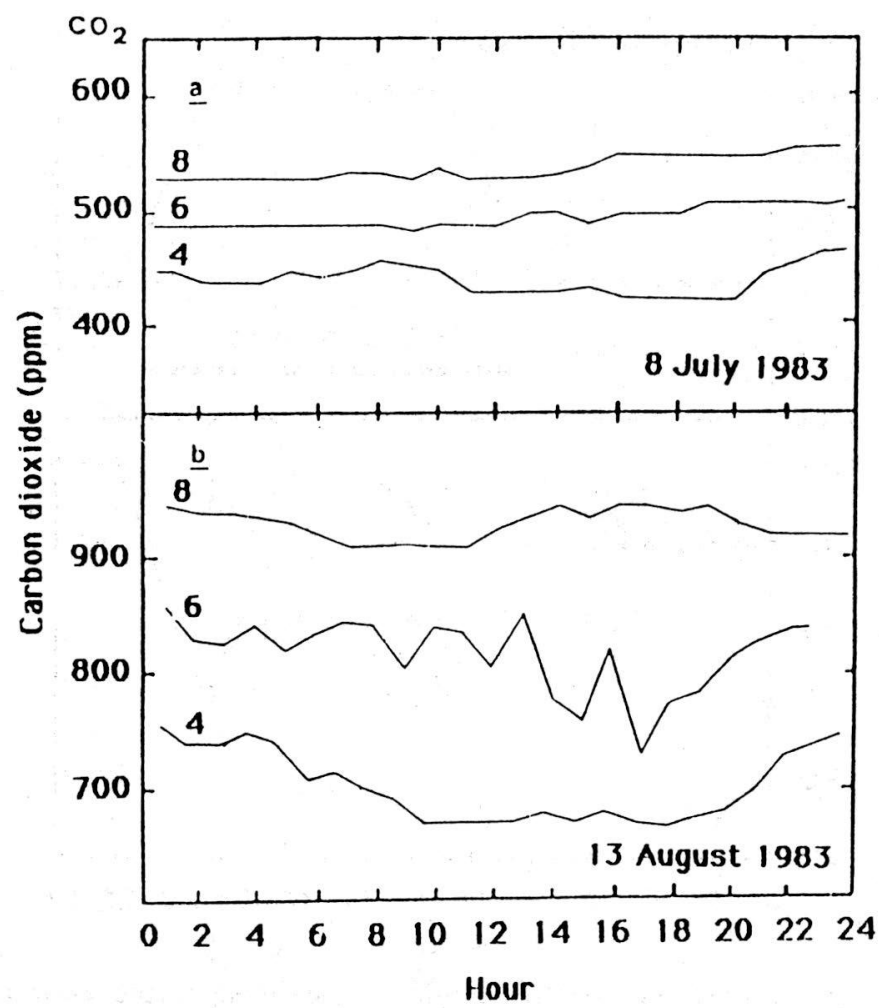

Fig. 5 - Carbon dioxide concentration measured hourly at the sampling stations $\mathrm{N}^{\circ} 4,6$ and 8 (Castellani, 1988).

\section{THE NEW AUTOMATIC MONITORING NETWORK}

A new monitoring system was installed two years ago. After its start up in November 1989 much more data are available because the following sensors are operating:

6 thermometers for air temperature

2 thermometers for water temperature

5 anemometers

6 hygrometers

2 pluviometers

2 barometers

Such sensors supply data on-line to a personel computer to record them and for any further elaboration. 
The data supplied by this network give a rather detailed situation of the climatological parameters of the cave environment. A comparison of different functions can give a lot of information on the single processes occurring in various parts of the cave.

E.g. in Fig. 6. the comparison of the diagrams of inside and outside temperatures and of the air velocity shows the change of direction of the air flow at the upper entrance of the Ancona Hall when the function of outside air temperature crosses the line of inside air temperature. In the case of the Falconara Pitch there is a variation of the air velocity without changes of the flow direction. Many other interesting features were observed which will be reported in other publications.

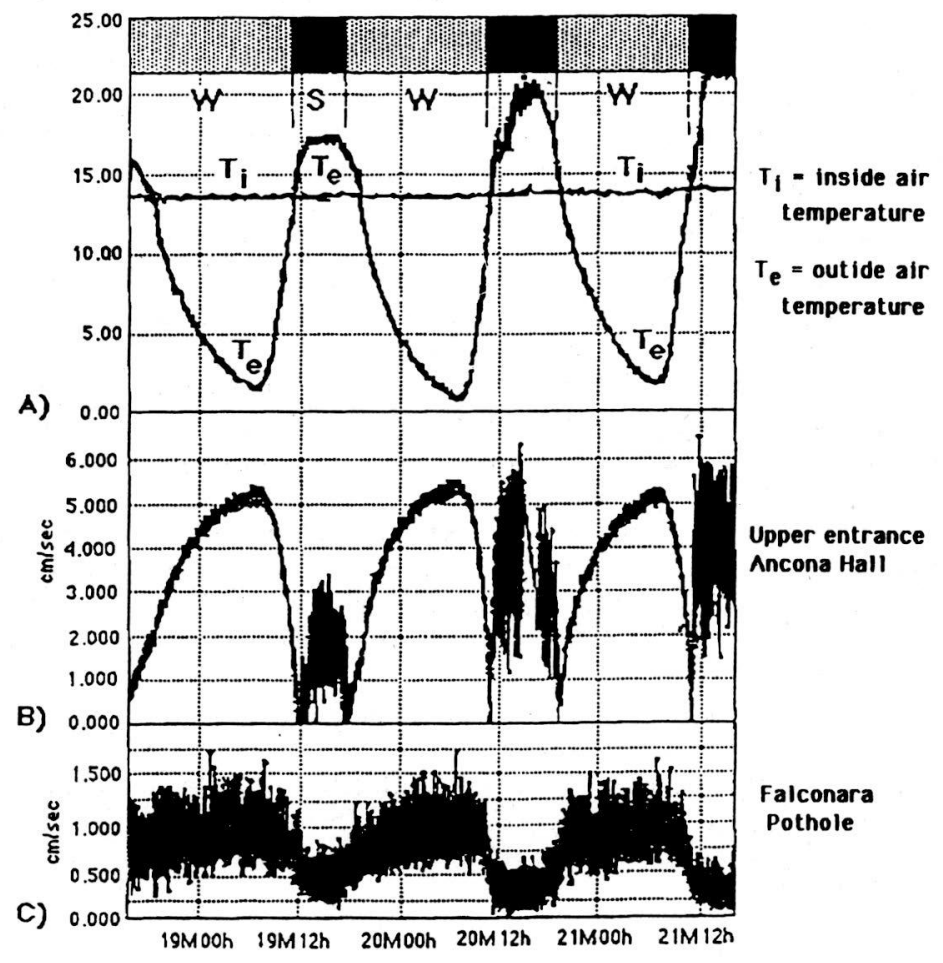

Fig. 6 - Diagrams of inside and outside air temperature and of the air velocity at the upper entrance of the Ancona Hall and in correspondence of the Falconara pothole. It is evident the change of direction of the air flow at the upper entrance of the Ancona Hall when the function of outside air temperature crosses the line of inside temperature. In the case of the Falconara pothole there is a variation of the air velocity without changes of the flow direction (Dragoni \& Verdacchi, 1990). 


\section{SCIENTIFIC RESEARCHES}

The problems deriving from the exploitation of show caves in connection with the preservation of the cave environment deserv ed much attention by the public opinion in last years. The results obtained in the "Grotta Grande del Vento» were presented in many congresses and meetings in such arguments (Bertolani 1982, 1983; Cigna \& Forti 1989; Forti \& Cigna 1989; Galdenzi \& Menichetti (Eds .) 1990).

The Commission, which initially was appointed by the Consorzio Frasassi to advice on the cave management, has also a role for promoting and coordinating scientific researches supported directly by the Consorzio itself: a certain amount of its budget is devoted each year to this purpose.

A study on the hydrogeochemistry of the cave, directed by G.P. Sighinolfi of the University of Modena (1989), identified 3 kinds of waters: one directly originated by precipitations, one enriched of sulfide hydrogen and with a deep origin and a third one deriving from the aquifer of the Sentino creek. Another study carried on by A. Taddeucci (Univ. of Rome) dated some speleothems coll ected in different parts of the cave: ages varying from 190,000 years ago to present were found (Taddeucci A. \& Conte A.) A research on cave fauna under the leadership of $R$. Bertolani (Univ. of Modena) supplied a wide review of the species found in the whole karst complex (Bertolani R. et al., 1990).

In addition other studies, supported by ENEA, were carried out in this cave concerning, respectively, the radon concentration measured inside (Cigna A.A. \& Clemente G.F., 1981; Cigna A.A. 1986) and the dating of some karst reservoirs (Cigna A.A. \& Giorcelli F.G. 1988).

A research on physical problems and particularly on speleogenetic processes is now in course under the direction of V. Castellani (Univ. of Pisa) and W. Dragoni (Univ. of Perugia); another one on the cave minerals will be carried on in the very near future by A. Rossi (Univ. of Modena) and P. Forti (Univ. of Bologna).

It must be emphasized the essential support of the Consorzio Frasassi which is not limited to a regular management of the show cave according to the principles of the environmental protection (which is already something very important!). The scientific researches financed by the Consorzio act as a catalyst for studies to be developed in the Universities and fill a gap otherwise left aside.

\section{REFERENCES}

Bertolani M., 1982 - I problemi dell'integritd della Grotta Grande del Vento (Genga, Ancona) e $i$ provvedimenti di controllo ambientale e di difesa. Atti Conv. Int. Grotte turistiche, Borgio Verezzi 20/23-3-1981, le Grotte d'Italia, (4) 10: 73-78.

Bertolani M., 1983 - Premières données sur le contrôle du milieu de la «Grotta Grande del Vento» (Ancona, Italie). Proc. Int. Meeting on the 
Show Caves and their Problems, Athens, Sept. 1-4, 1983.

Bertolani M., Garuti G., Rossi A., 1975 - The speleologic complex "Grotta Grande del Vento-Grotta del Fiume» in the Frasassi Canyon (Ancona, Italy). A petrological and mineralogical study. Proc. 6th Int. Congr. Speleology, Olomouc 1973, 1, Ab:357-366.

Bertolani M., Garuti G., Rossi A., Bertolani Marchetti D., 1976 - Motivi d'interesse mineralogico-petrografico nel complesso carsico "Grotta Grande del Vento-Grotta del Fiume» (Genga, Ancona). Le Grotte d'Italia, (4) 6: 109-144.

Bertolani R., Manicardi G.C., Rebecchi L., 1990 - Faunistic study in the karst complex of Frasassi (Genga, Ancona, Central Italy). Proc. 1st Int. Congr. ISCA, S. Vittore Terme, 1-4 November 1990.

Castellani V., 1988 - Frasassi e speleomonitoraggio. Speleologia, Rivista della S.S.I., Milano, 9 (18):33-35.

Cigna A.A., 1986 - Radon Concentration in Some Italian Caves. Proc. 9 Congr. Int. Espeleologia, Barcelona (Spain), 2: 84-88.

Cigna A.A. \& Forti p., 1989 - The environmental impact assessment of a tourist cave. Cave Tourism. Proc. Int. Symp. 170th Anniv. Postojnska Jama, Postojna, Nov. 10-12, 1988. Centre Scient. Res. SAZU \& Postojnska Jama Tourist and Hotel Organiz.: 29-38.

Cigna A.A. \& Clemente G.F., 1981 - Radiation Hazards in Natural Caves. Proc. 8 Int. Congr. Speleology, Bowling Green ( USA), 2: 420-423.

Cigna A.A. \& Giorcelli F.G., 1988 - Underground water dating by tritium measurements. Proc. 10th Congr. Speleology, Budapest, Magyar Karztés Barlangkutató Társulat, 2: 562-563.

Consorzio Frasassi, 1990 - Personal communication.

Direzione Grotte di Castellana, 1990 - Personal communication.

Dragoni W. \& Verdacchi A., 1990 - First results of the monitoring system of the karstic complex of "Grotte di Frasassi-Grotta Grande del Vento" Central Apennines, Italy». Proc. Int. Symp. on Hydrogeologic Processes in Karst Terrains, Oct. 7-16, 1990, Antalya, Turkey.

Forti P. \& Cigna A.A., 1989 - Cave Tourism in Italy: an overview. Proc. Int. Symp. on 170th Anniv. of Postojnska Jama. Postojna 10-12 November 1988.

Galdenzi S. \& Menichetti M. (Eds.), 1990 - Il carsismo della Gola di Frasassi. In: Il carsismo della Gola di Frasassi. Proc. Conv. Naz. «Il carsismo della Gola di Frasassi», Nov. 1989; Mem. Ist. It. Speleol., 4, s. 2: 109-122.

Sighinolfi G.P., 1990 - Studio chimico delle acque del complesso "Grotte di Frasassi» (Ancona). Implicazioni speleogenetiche ed ambientali. In: Il carsismo della Gola di Frasassi. Proc. Conv. Naz. «Il carsismo della Gola di Frasassi", Nov. 1989; Mem. Ist. It. Speleol., 4, s. 2: 109-122.

Taddeucci A. \& Conte A., 1987 - Datazione col 230Th di alcuni speleotemi del complesso carsico "Grotta del Fiume-Grotta Grande del Vento" a Frasassi (Ancona). Boll. Soc. Geol. It., 106: 807-812. 